Науковий вісник Дьвівського націонадьного університету ветеринарної медицини та біотехнологій імені С.З. Гжицького

\author{
Scientific Messenger of Lviv National University \\ of Veterinary Medicine and Biotechnologies
}

\title{
The development of the digestive system in broiler chickens at different levels of selenium into the mixed fodder
}

\author{
O. Sobolev ${ }^{1}$, B. Gutyj ${ }^{2}$, R. Petryszak ${ }^{2}$, I. Golodjuk ${ }^{2}$, O. Naumyuk ${ }^{2}$, O. Petryszak ${ }^{2}$ \\ ${ }^{1}$ Bila Tserkva National Agricultural University, Bila Tserkva, Ukraine \\ ${ }^{2}$ Stepan Gzhytskyi National University of Veterinary Medicine and Biotechnologies Lviv, Ukraine
}

Article info

Received 02.02.2018 Received in revised form 28.02 .2018

Accepted 06.03.2018

Bila Tserkva National Agricultural University, Soborna sq., 8/1, Bila Tserkva, 09100, Ukraine. Tel.:+38-096-443-91-50 E-mail: sobolev_a_i@ukr.net

Stepan Gzhytskyi National University of Veterinary Medicine and Biotechnologies Lviv, Pekarska str., 50, Lviv, Ukraine. Tel.:+38-068-136-20-54 E-mail:bvh@ukr.net
Sobolev O., Gutyj B., Petryszak R., Golodjuk I., Naumyuk O., \& Petryszak O. (2018). The development of the digestive system in broiler chickens at different levels of selenium into the mixed fodder. Scientific Messenger of Lviv National University of Veterinary Medicine and Biotechnologies. 20(84), 83-87. doi: 10.15421/nvlvet8415

Scientific studies of foreign and domestic scientists convincingly proved that selenium is a vitally necessary trace element for farm animals and birds with a wide range of biological effects. It performs unique multifunctional functions in the body - structural, catalytic, regulatory, possesses antioxidant, anti-carcinogenic radioprotective, immunostimulant, antiviral, anti-mutagenic, anti-toxic and adaptogenic properties, participates in the formation of mechanisms that determine the reproductive function of animals and birds, affects osteogenesis, participates in the processes of growth and development. In the scientific and economic research the influence of additives of various doses of selenium into mixed fodder on the development of the digestive system in broiler chickens was studied. As a source of selenium, selenite sodium was used. The research was conducted in the production conditions on broiler chickens of the COOB 500 cross. The duration of the experiment corresponded to the period of growing the young for meat and was 42 days. It was established that the use of selenium in the composition of mixed fodder for broiler chickens at doses of 0.3; 0.4 and $0.5 \mathrm{mg} / \mathrm{kg}$ positively influenced the development of the digestive system in young, in particular, contributed to an increase in the mass (by 4.1$11.6 \%)$ and total length (1.3-3.5\%) of the intestine in general, and its thin and thick parts in particular, as well as the mass of the muscular stomach (17.3-23.2\%) and liver (3.6-10.0\%). The best macromorphological parameters of the digestive system development were chicken broilers, which, during the entire period of growing, mixed fodder, were enriched with selenium at a rate of $0.3 \mathrm{mg} / \mathrm{kg}$. Comparison of the live weight of broiler chickens of experimental groups with indicators of intestinal development, muscular stomach and liver allows us to assume that the digestive systems in them have been developed better and during the growing period they function more actively.

Key words: selenium, dose, mixed fodder, broiler chickens, intestines, muscular stomach, liver.

\section{Розвиток травної системи у курчат-бройлерів за різного рівня селену в комбікормах}

\author{
О.І. Соболєв ${ }^{1}$, Б.В. Гутий${ }^{2}$ Р.А. Петришак ${ }^{2}$, І.П. Голодюк ${ }^{2}$ О.С. Наумюк ${ }^{2}$, О.Й. Петришак ${ }^{2}$ \\ Білоцерківський національний аграрний університет, м. Біла Церква, Украйна \\ Львівський національний університет ветеринарної медицини та біотехнологій імені С.3. Гљицького, \\ м. Львів, Україна
}

Наукові дослідження зарубіжних і вітчизняних учених переконливо довели, щүо селен є життєво необхідним мікроелементом для сільськогосподарських тварин і птиці з широким спектром біологічної дї. Він виконує в організмі унікальні багатопланові функиії-структурну, каталітичну, регуляторну, володіє антиоксидантними, антиканцерогенними радіопротекторними, імуностимулюючими, антивірусними, антимутагенними, антитоксичними та адаптогенними властивостями, бере участь у формуванні механізмів, які визначають відтворювальну функиію тварин і птиці, впливає на остеогенез, бере участь у процесах росту та розвитку. У науково-господарському досліді вивчено вплив добавок різних доз селену в комбікорми на розвиток травної системи у 
курчат-бройлерів. Як джерело селену, використовували селеніт натрію. Дослідження проводилися у виробничих умовах на курчатах-бройлерах кросу СОВВ 500. Тривалість досліду відповідала періоду вирошування молодняку на м'ясо і становила 42 дні. Встановлено, шо використання селену в складі комбікормів для курчат-бройлерів у дозах 0,3; 0,4 та 0,5 мг/кг позитивно вплинуло на розвиток травної системи у молодняку, зокрема сприяло збільшенню маси (на 4,1-11,6\%) та загальної довжини (на 1,3-5,4\%) кишечнику загалом і його тонкого та товстого відділів зокрема, а також маси м'язового шлунка (на 17,3-23,2\%) та печінки (на 3,6-10,0\%). Кращі макроморфологічні показники розвитку травної системи мали курчата-бройлери, комбікорми яких, упродовж усього періоду вирощування, збагачували селеном із розрахунку 0,3 мг/кг. Співставлення живої маси курчат-бройлерів дослідних груп з показниками розвитку кишечнику, м'язового шлунка та печінки дозволяє стверджувати, щзо органи травлення у них були розвинуті краще та упродовж періоду вирощування функціонували більш активно.

\section{Ключові слова: селен, доза, комбікорм, курчата-бройлери, кишечник, м'язовий шлунок, печінка.}

\section{Вступ}

М'ясне птахівництво є однією із найбільш динамічних і економічно ефективних галузей агропромислового комплексу, здатною у найближчі роки докорінно поліпшити забезпечення населення України високоякісним дієтичним м'ясом та зміцнити продовольчу безпеку держави (Grygor'jev, 2016).

Результати наукових досліджень та практичний досвіт вирощування курчат-бройлерів показують, що запорукою максимальної реалізації генетичного потенціалу, високої продуктивності та збереження молодняку, конверсії корму є повноцінна годівля, яка передбачає повне задоволення індивідуальної потреби птиці в обмінній енергії, поживних і біологічно активних речовинах, у тому числі й мікроелементах.

Мікроелементи активують дію багатьох ферментів, вітамінів, гормонів і цим забезпечують нормальне функціонування різних біологічних систем, здійснення численних фізіолого-біохімічних реакцій в організмі i, як наслідок, впливають на продуктивні якості та життєздатність птиці (Richards et al., 2010; Hunchak et al., 2017). У зв'язку з тим, що мікроелементи не синтезуються в організмі й не можуть бути замінені іншими речовинами, основним джерелом надходження їх в організм птиці $є$ комбікорми. Мікроелементи вводяться до складу комбікормів у вигляді гарантованих добавок (Taylor-Pickard and Tucker, 2005; Medvid et al., 2017).

Сучасна система нормованої годівлі сільськогосподарської птиці передбачає обов'язкове введення до комбікорму для курчат-бройлерів семи мікроелементів, серед яких особливе місце посідає селен завдякисвоїй біохімічній багатогранності (Bratishko et al., 2013).

Наукові дослідження вітчизняних і зарубіжних учених у галузі фізіології, біохімії, медицини та ветеринарії переконливо довели, що селен виконує в організмі унікальні багатопланові функції - структурну, каталітичну, регуляторну, володіє антиоксидантними, антиканцерогенними радіопротекторними, імуностимулюючими, антивірусними, антимутагенними, антитоксичними та адаптогенними властивостями. Він бере участь у формуванні механізмів, які визначають відтворювальну функцію тварин і птиці, впливає на остеогенез, бере участь у процесах росту та розвитку (Reilly, 2013; Khariv et al., 2017; Sobolev et al., 2018).

Відкриття біологічних властивостей селену стало підставою для використання його у птахівництві спочатку в профілактиці та лікуванні хвороб, пов'язаних iз дефіцитом цього мікроелемента, а згодом - 3 метою підвищення продуктивності сільськогосподарської птиці, поліпшення якості їхньої продукції та виробництва дієтичних харчових продуктів функціонального призначення 3 біокорегувальною дією (Surai and Fisinin, 2014; Sobolev et al., 2017).

У різних країнах норми введення селену у комбікорми для курчат-бройлерів приблизно однакові та коливаються в межах від 0,2 до 0,5 мг/кг. Проте вони періодично переглядаються із появою нових кросів птиці та селеновмісних препаратів, які відрізняються від неорганічних форм селену високою біологічною доступністю (Surai et al., 2017).

Незважаючи на значну кількість наукових напрацювань щодо питання селенового живлення сільськогосподарської птиці, деякі аспекти впливу селеновмісних препаратів на іiі організм курчат-бройлерів або остаточно не з'ясовані, або залишилися поза увагою вчених, або не знайшли свого відображення у наукових статтях.

Відомо, що ріст і подальша продуктивність птиці нерозривно пов'язані з розвитком органів травлення, де відбуваються складні фізико-хімічні перетворення поживних речовин, що надійшли 3 кормом. Під впливом різних кормових факторів у травній системі птиці спостерігаються фізіологічні зміни (Lilburn and Loeffler, 2015).

У науковій літературі є окремі повідомлення про те, що введення в комбікорми для птиці добавок селену у вигляді різних сполук сприяє кращому розвитку ii шлунково-кишкового тракту. Проте дослідження, присвячені цьому питанню, виконані переважно на курях-несучках (Kuleshov, 2010), ремонтному молодняку курей (Okolelova and Savchenko, 2005), каченятах (Soboliev, 2016; Sobolev et al., 2017) і гусенятах (Soboliev and Povoznikov, 2016), що вирощуються на м'ясо.

У зв'язку з недостатньою кількістю публікацій у науковій літературі та суперечливістю деяких даних щодо впливу різних доз уведення селену до складу комбікормів для курчат-бройлерів на розвиток їхньої травної системи, виникла необхідність додаткових експериментальних досліджень.

Мета $i$ завдання дослідження - вивчити вплив добавок селену в комбікорми на розвиток травної системи у курчат-бройлерів.

\section{Матеріал і методи досліджень}

Експериментальна частина роботи виконана на кафедрі дрібного тваринництва Білоцерківського національного аграрного університету та у виробни- 
чих умовах. Дослідження проводилися на курчатахбройлерах кросу СОВВ 500.

Для проведення науково-господарського досліду формували групи із добових курчат за принципом аналогів $з$ урахуванням походження, статі, живої маси та фізіологічного стану (рухливість, стан оперення та ін.) (Fisinin, 2013). Тривалість досліду відповідала періоду вирощування курчат-бройлерів на м'ясо i становила 42 дні.

Птиці контрольної групи протягом періоду вирощування згодовували комбікорми, збалансовані за всіма основними поживними та біологічно активними речовинами. Молодняку дослідних груп у комбікорми додатково вводили різну кількість селену згідно зі схемою досліду (табл. 1).

\section{Таблиця 1}

Схема науково-господарського досліду на курчатахбройлерах

\begin{tabular}{lcc}
\hline \multicolumn{1}{c}{ Група } & $\begin{array}{c}\text { Кількість } \\
\text { птиці у групі, } \\
\text { гол. }\end{array}$ & $\begin{array}{c}\text { Добавка в комбікорми } \\
\text { селену, мг/кг }\end{array}$ \\
\hline 1 контрольна & 100 & Основний раціон (ОР) \\
2 дослідна & 100 & ОР $+0,3$ \\
3 дослідна & 100 & OP $+0,4$ \\
4 дослідна & 100 & OP $+0,5$ \\
\hline
\end{tabular}

У науково-господарському досліді як джерело селену використовували селеніт натрію класифікації «Ч» (ТУ 6-09-17-209-88, зареєстрований в ідентифікаторі хімічних сполук (CAS) за номером 10102-18-8), 3 коефіцієнтом перерахунку елемента в сіль 2,2.

Курчата-бройлери вирощувалися у пташнику на підлозі, з використанням обладнання ОПБ-2/12, при вільному доступі до води і корму, 3 дотриманням технологічних параметрів щільності посадки, мікрок- лімату та освітлення відповідно до існуючих норм (Galibarenko et al., 2005).

По закінченні науково-господарського досліду було відібрано по 4 голови (2 самки та 2 самці) птиці 3 кожної групи згідно з ДСТУ 3136-95 (DSTU, 1996) і у віваріумі Білоцерківського НАУ проведено їх контрольний забій відповідно до загальноприйнятої методики. Після контрольного забою курчат-бройлерів проводили їх повне анатомічне розбирання згідно з існуючими рекомендаціями (Lukashenko, 2013).

Результати досліджень опрацьовували стандартними методами варіаційної статистики з використанням алгоритмів М.О. Плохінського. При математичному опрацюванні результатів досліджень використовували ПОМ і застосовували комп'ютерні програми статистичної обробки Microsoft Excel. Оцінку вірогідності різниці між групами проводили за критерієм Стьюдента.

\section{Результати та їх обговорення}

Результати науково-господарського досвіду показали, що найвищі показники росту мав молодняк, якому впродовж періоду вирощування згодовували комбікорми, збагачені селеном, із розрахунку 0,3 мг/кг (табл. 2). Введення селену в комбікорми у такій кількості сприяло підвищенню живої маси курчатбройлерів другої дослідної групи на 5,1\% (Р < 0,01), порівняно $з$ молодняком контрольної групи, у якого аналогічні показники становили 2188,4 г. При більш високих дозах уведення селену в комбікорми $(0,4$ та 0,5 мг/кг) піддослідний молодняк за живою масою також перевищував курчат з контрольної групи, але різниця була дещо нижчою. Зокрема, у третій та четвертій дослідних групах вона становила 3,4 та 2,6\% відповідно.

\section{Таблиця 2}

Макроморфологічні показники органів травлення у курчат-бройлерів, $\bar{X} \pm S_{\bar{X}}$

\begin{tabular}{lcccc}
\hline \multicolumn{1}{c}{ Показник } & \multicolumn{3}{c}{ Група } \\
\cline { 2 - 5 } & 1 контрольна & 2 дослідна & 3 дослідна & 4 дослідна \\
\hline Передзабійна маса птиці, г & $2188,4 \pm 28,78$ & $2301,0 \pm 28,32^{* *}$ & $2263,5 \pm 23,19^{*}$ & $2245,8 \pm 31,79$ \\
Довжина кишечнику всього, см & $220,5 \pm 1,87$ & $232,5 \pm 3,32^{*}$ & $228,0 \pm 2,05^{*}$ & $223,3 \pm 3,61$ \\
у т.ч. тонкого відділу & $209,6 \pm 1,32$ & $220,8 \pm 2,76^{*}$ & $216,7 \pm 2,02^{*}$ & $212,6 \pm 3,98$ \\
$\quad$ товстого відділу & $10,9 \pm 0,60$ & $11,7 \pm 0,55$ & $11,3 \pm 0,87$ & $10,6 \pm 0,49$ \\
Маса кишечнику, г & $140,2 \pm 2,07$ & $156,5 \pm 3,14^{* *}$ & $149,3 \pm 1,91^{*}$ & $146,0 \pm 2,62$ \\
\% до передзабійної маси & 6,4 & 6,8 & 6,6 & 6,5 \\
Маса м’язового шлунка, г & $50,3 \pm 2,07$ & $62,0 \pm 2,91^{*}$ & $59,0 \pm 3,09$ & $60,2 \pm 3,54$ \\
\% до передзабійної маси & 2,3 & 2,7 & 2,6 & 2,7 \\
Маса печінки, г & $41,8 \pm 1,36$ & $46,0 \pm 2,05$ & $45,5 \pm 1,80$ & $43,3 \pm 2,37$ \\
\% до передзабійної маси & 1,9 & 2,0 & 2,0 & 1,9 \\
\hline Примітка: вірогідність різниці між контрольною та дослідними групами: ${ }^{*}-\mathrm{P}<0,05 ;^{* *}-\mathrm{P}<0,01$. &
\end{tabular}

Аналіз результатів вивчення розвитку органів травлення у курчат-бройлерів виявив деякі відмінності між групами, які, на нашу думку, обумовлені опосередкованою дією різних доз селену. Встановлено, що у молодняку дослідних груп зросла загальна довжина кишечнику на 1,3-5,4\%, порівняно з птицею контрольної групи (220,5 см). Проте статистично вірогідною
$(\mathrm{P}<0,05)$ різниця виявилася лише у другій та третій дослідних груп, курчата яких перевищували за цим показником своїх ровесників 3 контрольної групи на 12,0 та 7,5 см відповідно.

Варто зазначити, що збільшення загальної довжини кишечнику птиці дослідних груп відбулося в основному за рахунок збільшення лінійних розмірів тонкого відділу. Так, довжина тонкого відділу кишечнику 
у молодняку другої дослідної групи підвищилася на $5,3 \%(\mathrm{P}<0,05)$, третьої - на 3,4 (P <0,05), а четвертої - на 1,4\%, порівняно з аналогічним показником контрольної групи (209,6 см).

На наш погляд, даний факт є важливим, тому що саме в тонкому відділі кишечнику птиці відбуваються основні процеси ферментативного гідролізу поживних речовин корму та їх всмоктування. У результаті збільшення довжини тонкого відділу кишечника збільшується час проходження кормових мас по ньому i, як наслідок, збільшується час дії ферментів на хімус. А відтак - перетравність і засвоюваність поживних речовин корму в організмі птиці поліпшується. Це певною мірою пояснює вищі показники живої маси у курчат-бройлерів дослідних груп.

Відмінності між групами за лінійними розмірами товстого відділу кишечнику виявилися незначними, а різниця - не статистично вірогідною. Так, його довжина у птиці другої та третьої дослідних груп, порівняно 3 контрольною групою, збільшилася на 0,8 та 0,4 см відповідно. Різниця між четвертою дослідною та контрольною групами за цим показником становила 0,3 см на користь останньої.

Привертає увагу і той факт, що у птиці всіх дослідних груп збільшилася маса кишечнику. Порівняно 3 контрольною групою, різниця за його абсолютною масою у другій дослідній групі становила 11,6\% $(\mathrm{P}<0,01)$, у третій $-6,5(\mathrm{P}<0,05)$ та у четвертій $4,1 \%$. Стосовно до передзабійної маси птиці, маса кишечнику збільшилась у курчат-бройлерів дослідних груп відповідно на 0,$4 ; 0,2$ та $0,1 \%$

Уведення селену до складу комбікормів позитивно вплинуло на формування і розвиток м'язового шлунка курчат-бройлерів (59,0-62,0 г проти 50,3 г у контрольній групі). Найбільш розвиненим він виявився у молодняку другої дослідної групи $(62,0$ г), якому в комбікорми вводили селен у кількості 0,3 мг/кг. Різниця, порівняно 3 контрольною групою, становила 23,2\% ( $<$ < 0,05). У птиці третьої та четвертої дослідних груп різниця за цим показником виявилася також суттєвою - 17,3 та 19,7\% відповідно, хоча не була статистично вірогідною. Питома віга м'язового шлунка у курчат-бройлерів дослідних груп, порівняно 3 аналогічним показником у контрольній групі, підвищилася на $0,3-0,4 \%$.

Беручи до уваги фізіологічну роль найбільшої залози зовнішньої секреції - печінки та жовчі, яку вона виробляє, у перетравленні корму, обміні білків, вуглеводів, жирів, гормонів, вітамінів, знешкодженні та детоксикації багатьох ендогенних і екзогенних речовин, ми дослідили іiі розвиток у піддослідної птиці. Варто зазначити, що у молодняку дослідних груп спостерігалася тенденція до підвищення маси печінки. Різниця між контрольною та дослідними групами (на користь останніх) становила: у другій - 10,0\%, у третій $-8,8$ та четвертій $-3,6 \%$.

\section{Висновки}

Використання селену в складі комбікормів для курчат-бройлерів у дозах, які вивчалися, позитивно вплинуло на розвиток травної системи у молодняку, зокрема, сприяло збільшенню маси та загальної довжини кишечнику загалом і його відділів зокрема, а також маси м'язового шлунка та печінки. Кращі макроморфологічні показники розвитку травної системи мали курчата-бройлери, комбікорми яких упродовж усього періоду вирощування збагачували селеном із розрахунку 0,3 мг/кг. Співставлення живої маси курчат-бройлерів дослідних груп з показниками розвитку кишечнику, м'язового шлунка i печінки дозволяє стверджувати, що органи травлення у них були розвинуті краще та упродовж періоду вирощування функціонували активніше.

\section{References}

Grygor'jev, S.O. (2016). Suchasnyj stan vyrobnyctva produkcii' ptahivnyctva v Ukrai'ni. Naukovyj visnyk Uzhgorods'kogo universytetu. Serija «Ekonomika». 1(47), 131-135 (in Ukrainian).

Hunchak, A., Ratych, I., Gutyj, B., \& Paskevych, H. (2016). Metabolic effects of iodine in poultry for its deficiency or excess in the diet. Scientific Messenger of LNU of Veterinary Medicine and Biotechnologies, 18(2(67), 70-76. doi: 10.15421/nvlvet6716.

Richards, J.D., Zhao, J., Harreil, R.J., Atwell, C.A., \& Dibner, J.J. (2010). Trace mineral nutrition in poultry and swine. Asian-Australasian Journal of Animal Sciences. 23(11), 1527-1534. doi: 10.5713/ajas.2010.r.07.

Taylor-Pickard, J.A., \& Tucker, L.A. (2005). Redefining mineral nutrition. Nottingham University Press. Nottingham.

Medvid, S., Hunchak, A., Gutyj, B., \& Ratych, I. (2017). Prospects of rational security chicken-broilers with mineral substances. Scientific Messenger of LNU of Veterinary Medicine and Biotechnologies. 19(79), 127-134. doi: 10.15421/nvlvet7925

Bratishko, N.I., Ionov, I.A., Ibatullin, I.I., Prytulenko, O.V., Klymenko, T.Je., Kotyk, A.M., Katerynych, O.O., Zhukors'kyj, O.M., Gavilej, O.V., Poljakova, L.L., \& Grycenko R.B. (2013). Efektyvna godivlja sil's'kogospodars'koi' ptyci. Agrarna nauka. Kyi'v (in Ukrainian).

Reilly, C. (2013). Selenium in Food and Health. Springer. Boston. doi: 10.1007/978-0-387-33244-4

Khariv, I., Gutyj, B., Hunchak, V., Slobodyuk, N., Vynyarska, A., Sobolta, A., Todoriuk, V., \& Seniv, R. (2017). The influence of brovitatoxide in conjunction with milk thistle fruits on the immune system of turkeys for eimeriozic invasion. Scientific Messenger of LNU of Veterinary Medicine and Biotechnologies. 19(73), 163-168. doi: 10.15421/nvlvet7334.

Sobolev, O., Gutyj, B., Petryshak, R., Pivtorak, J., Kovalskyi, Y., Naumyuk, A., Petryshak, O., Semchuk, I., Mateusz, V., Shcherbatyy, A., \& Semeniv, B. (2018). Biological role of selenium in the organism of animals and humans. Ukrainian Journal of Ecology Ukrainian Journal of Ecology. 8(1), 654-665. doi: $10.15421 / 2017263$. 
Surai, P., \& Fisinin, V.I. (2014). Selenium in poultry breeder nutrition: An update. Animal Feed Science and Technology. 191. 1-15. doi: 10.1016/j.anifeedsci.2014.02.005.

Sobolev, A., Gutyj, B., Grynevych, N., Bilkevych, V., Mashkin, Y. (2017). Enrichment of meat products with selenium by introducing mixed feeds for birds in their compound. Regulatory Mechanisms in Biosystems. 8(3), 417-422. doi: 10.15421/021764.

Surai, P., Kochish, I.I., Fisinin, V.I., \& Velichko, O.A. (2017). Selenium in poultry nutrition: from sodium selenite to organic selenium sources. The Journal of Poultry Science. doi: 10.2141/jpsa.0170132.

Lilburn, M.S., \& Loeffler, S. (2015). Early intestinal growth and development in poultry. Poultry Science. 94(7), 1569-1576. doi: 10.3382/ps/pev104.

Kuleshov, K.A. (2010). Postnatal'nyj morfogenez organov zheludochno-kishechnogo trakta kur pri primenenii selensoderzhashhih preparatov. Veterinarnaja patologija, 1, 57-66 (in Russian).

Okolelova, T., \& Savchenko, S. (2005). Sel-pleks stimuljator razvitija remontnogo molodnjaka kur. Pticevodstvo. 12, 23-24 (in Russian).

Soboliev, O.I. (2016). Rozvytok orhaniv shlunkovokyshkovoho traktu u kacheniat, shcho vyroshchuiutsia na miaso, za riznoho rivnia selenu v kombikormakh. Tekhnolohiia vyrobnytstva i pererobky produktsii tvarynnytstva. 2, 34-38 (in Ukrainian).

Sobolev, A., Gutyj, B., Petryshak, O., Golodjuk, I., Petryshak, R., \& Naumyuk, O. (2017). Morphological and biochemical blood indicators of ducklings, which are raised for the purpose of meat with the different level of selenium in feeding-stuffs. Scientific Messenger of LNU of Veterinary Medicine and Biotechnologies. 19(74), 57-62. doi: 10.15421/nvlvet7413.

Soboliev, O.I., \& Povoznikov, M.H. (2016). Vplyv dobavok selenu $\mathrm{v}$ kombikormy na rozvytok travnoi systemy u huseniat, shcho vyroshchuiutsia na miaso. Ahrarna nauka ta kharchovi tekhnolohii. 3, 100-105 (in Ukrainian)

Fisinin, V.I. (2013). Metodika provedenija nauchnyh i proizvodstvennyh issledovanij po kormleniju sel'skohozjajstvennoj pticy : rekomendacii. VNIITIP, Sergiev Posad (in Russian).

Galibarenko, M., Smirnov, O., Pasichnyi, V., Riabokon, Yu., Ivko, I., Melnyk, B., Pudov, V., Kulbaba, C., Duiunov, B., Sokhatskyi, M., Vashkulat, M., Kyreieva, I., Bulyha, N., \& Demydenko, V. (2005). VNTP-APK-04. 05. Pidpryiemstva ptakhivnytstva. Ministerstvo ahrarnoi polityky. Kyiv. http://online.budstandart.com/ua/catalog/docpage.html?id_doc=73513 (in Ukrainian).

DSTU 3136-95 (1996). Ptytsia silskohospodarska dlia zaboiu. Tekhnichni umovy. Derzhstandart Ukrainy. Kyiv (in Ukrainian).

Lukashenko, V.S. (2013). Metodika provedenija anatomicheskoj razdelki tushek, organolepticheskoj ocenki kachestva mjasa i jaic sel'skohozjajstvennoj pticy i morfologii jaic : metodicheskoe rukovodstvo. VNIITIP. Sergiev Posad (in Russian). 